gía ni un alegato racial, sino una obra de arte, una novela. Queda por destacar aún, junto a la veracidad pintoresca y natural de los diálogos, una prosa rica en belleza y sencilla en su construcción, directa, recortada, donde el vocablo araucano surge con oportunidad insustituible.-Antonio Pagés Larraya.

\title{
“Diógenes" $\mathrm{Y}$ OTROS ESCRITOS
}

El 8 de marzo de 1871 apareció el primer número del periódico Diógenes, que dirigía el acerado periodista chileno Justo Arteaga Alemparte. En aquellos años terminaba su mandato presidencial el astuto y flemático don Joaquín Pérez y se vislumbraba en el horizonte la candidatura oficial de don Federico Errázuriz. El quijotesco paladín que hubo en el espíritu ejemplar de Arteaga Alemparte, se aprestó para combatirlos. Lo hizo con una adjetivación cáustica, con una dialéctica de gran frescura, haciendo sentir a cada momento el localismo de nuestra patria frente a la vastedad del mundo. He aquí algunas de sus frases: "Cualquiera que sea la acogida que Díggenes encuentre en el público, me dirá de un modo bien claro, y sin que intervengan las lisonjas de la amistad, si un hombre que ha dirigido a su país la palabra durante largos años, puede llegar a formarse un hogar propio, un hogar libre, un hogar en que domine su voz, su pensamiento, su opinión". "Afirmamos sin rodeos, que tenemos antes los vicios que las virtudes de la democracia. Vanidad, envidia, celos, odio agreste e indomable a toda superioridad, he ahí nuestro mejor bagaje democrático. No hay otro país en que las mediocridades sean más festejadas ni sean más afortunadas. Estamos en la patria de la mediocridad".

De 1871 a 1957 no han variado grandemente las cosas; basta tratar de orientarse en cualquiera de nuestras actividades a fin de apreciar que los clanes y "patotas", que la solidaridad estrecha de los que ocultan una común flaqueza, llega a regirnos. Hay cierto 
odio solapado a la frente alta, que no estima indispensable ni el adulo ni la humillación para obtener un merecido beneficio. Cierta vez escuchamos a un integrante diestro de un grupito semipolítico y algo literario, que no carecía de importancia la forma de situar dos o tres nombres destinados al escalamiento de la gloria. La "gloire" que hizo lanzar una palabrota expresiva a Paul Verlaine frente a Rubén Darío.

Sin embargo, en la entrelínea de aquellas crónicas vigorosas de Justo Arteaga Alemparte, actuales por su misma vivacidad, se advierte que en aquellos años no existía crisis económica en Chile y que los problemas debatidos concernían más a la ética individual que a la lucha de clases. Ahí están para probarlo las invectivas que el articulista dirige al Intendente Echaurren, de Valparaíso, verdadero precursor de los agobiantes impuestos y trabazones legales modernas. El periódico Diógenes sólo alcanzó a publicar 19 números, pero sus retratos, semejantes a los que trazó acerca de los personajes de la vida literaria, en otra publicación efímera, Balzac, en París, son inolvidables. El lector contempla vivos, sin estar descritos, pero cogidos en su inasible profundidad, a don Benjamín Vicuña Mackenna, a don Miguel Luis Amunátegui, a don Aníbal Pinto.

Don Justo Arteaga Alemparte tenía una concepción dinámica del periodismo; no lo estimaba tribuna para exhibir cultura, ni aceptaba el paso tardo de la sesudez erudita, veía en la tarea cotidiana del diarista la posibilidad de proyectar una luz poderosa y breve en los problemas de mayor complejidad, con cierta exigencia inexorable hacia los hombres, de labor constructiva y de honradez.

La reaparición actual de Diógenes, con el patrocinio del Servicio de Cultura y Publicaciones del Ministerio de Educación, nos ha llevado a pensar en la vocación periodística, tan semejante a la del sacerdocio o a la del médico apóstol, sin asomos de comercialismo. Es probable que no exista escuela ni puntaje universitario que otorgue esa vocación si no se lleva en la sangre.-L. A. M. 